\title{
Impacts of Colombo-Katunayake Expressway Bridge Opening on Water Quality at Madabokka in Negambo Lagoon, West Coast of Sri Lanka
}

\author{
Priyadarshani W.N.C.", Arulananthan K. and Prasad J.A.C. \\ National Aquatic Resources Research and Development Agency, \\ Mattakkuliya, Sri Lanka \\ "Nilanthi_priyadarshani@yahoo.com
}

\begin{abstract}
The proposed 5 year Colombo- Katunayake expressway construction project which is target to reduce travelling time between Colombo and Katunayake international airport in Sri Lanka. This project would build 42 bridges and 88 culverts. One of the bridges opened at Madabokka inside the Negambo Lagoon is identified as highly productive ecosystem which provides breeding, feeding and security grounds for variety of aquatic lives. Thus, current Study the seasonal impact on Madabokka is carried out using water quality analysis.
\end{abstract}

Water samples from nine locations of three main sites (southern side, Northern side and outside of the Madabokka) are analysed for physical, (temperature, salinity, $\mathrm{pH}$ and transparency or sechchi depth) chemical, $\left[\mathrm{NO}_{3}, \mathrm{NO}_{2}, \mathrm{PO}_{4}, \mathrm{SiO}_{2}\right.$, Total suspended solids (TSS), and Dissolved Oxygen (DO)], and biological parameters (chlorophyll a, phytoplankton and zooplankton) once in two months during the year 2012.

Results indicate that average salinity and temperature are varied from 14.24-24.54 PSU and $31^{\circ} \mathrm{C}$ (September) $-34^{0} \mathrm{C}$ (March) respectively, while the warmest water is existed in southern part of Maddabokka which has no free exchange with Negambo lagoon. However, the observed spatial and temporal variation would be related to climatic conditions rather than bridge constructions. Both the lowest (4.6) and the highest values (7.9) $\mathrm{pH}$ values and were recorded outside Maddabokka during June and March respectively. Low $\mathrm{pH}$ values in month of June would be associated with South-West monsoon and particular low values could be a result of fresh water runoff canals from Katunayake airport area. Sechchi depth is always $\leq 1.00 \mathrm{~m}$ and higher depth remained as turbid water due to rapid constructions. DO values are varied from $5.9-8.3 \mathrm{mg} \mathrm{l}^{-1}$ with no impacts from the bridge constructions. TSS values are varied from 13.9-84.3 $\mathrm{mg} \mathrm{l}^{-1}$ and the highest value is recorded in southern side of the bridge during November. Level of nutrients, (Nitrite; 0.05-5.34 $\mathrm{mg} \mathrm{l}^{-1}$, Nitrate; 0.06-0.17 $\mathrm{mgl}^{-1}$, Phosphate; 0.00-0.84 mg l-1 Silicates; $2.68-14.88 \mathrm{mg} \mathrm{l}^{-1}$ ) are varied temporally and there is no construction interferences. Chlorophyll $a\left(1.10-20.51 \mathrm{mg} \mathrm{l}^{-1}\right)$ is distinctive in temporally and no spatial variations. The highest abundance (355000 Ind/L) of Phytoplankton are recorded in Southern side of the bridge in March. All guilds were dominated by centric diatoms. The lowest and the highest Zooplankton abundance ( $27 \mathrm{ind} / 1$ and $530 \mathrm{ind} / \mathrm{L}$ ) are recorded at outside of Madabokka during March and September respectively. Species diversity ( 7 groups) is high in southern part of the Madabokka and dominated by Calanoids in June and November.

Keywords: Negambo, Expressway, Water quality, Plankton 